UDC 9.502.4:502.5/8

\author{
Alina Yuriivna Ovcharenko, \\ $\mathrm{PhD}$ Student (Geography), V. N. Karazin Kharkiv National University, \\ 4 Svobody Sq., Kharkiv, 61022, Ukraine, \\ e-mail: alina06ov@ukr.net, https://orcid.org/0000-0002-8500-4152
}

\title{
RECOGNITION OF INDICATIVE LANDSCAPE OBJECTS WITHIN PROTECTED AREAS
}

А. Ю. Овчаренко. ВИЯВЛЕННЯ ІНДИКАТИВНИХ ЛАНДШАФТНИХ ОБ'СКТІВ В МЕЖАХ ПРИРОДООХОРОННИХ ТЕРИТОРІЙ. Робота присвячена ідентифікації ландшафтних об'єктів (рослинні угруповання та водні об'єкти), які змінюються впродовж часу $і$ впливають на структуру ландшафтних комплексів. Територія дослідження знаходиться 6 межах природоохоронної зони, тому важливим аспектом виявлення індикаторів зміни ландщафтів рівня фацій є дистаниійні методи дослідження. Створення образу ландмафтної мозайки за допомогою космічних знімків Sentinel-2, Planet Scope, Landsat 8 дозволяє укласти карту-гіпотезу, сформувати базу даних та проаналізувати образ, який створений дистанційно. Автором було уточнено методику укладання ландшафтної карти та виявлення індикативних об 'єктів і проведено експериментальні роботи щзодо вибору даних космічних знімків та інструментарію обробки. Обробка даних космічних знімків дає можливість аналізувати важкодоступні території, наприклад ті, щчо знаходяться в зоні підвищеної охорони чи райони 6 містах боліт, густих лісів, гір і т. д. У процесі укладання методичних аспектів було використано і апробовано декілька методів класифікаиії космічних знімків: використовували автоматичну і ручну обробку. Зокрема, кращі результати отримані методом контрольованої класифікації. Вибір космічних знімків і його просторового розщирення залежить від задач, поставлених перед дослідником, площі території, характеру різноманітності об 'єктів та наявність можливостей покупки чи відкритого використання даних. Вибір індикаторів значно залежить від технічної обробки даних, візуального та програмного аналізу окремої території. Для природоохоронних території важливо враховувати специфіку місцевості та характер змінності образу ландшафтів під впливом природних та антропогенних факторів (так як природоохоронні територіі зазнають вплив від господарської діяльності людини і створенні як природні резервати екосистем та їх окремих компонентів). Виявлення індикаторів дозволяе проаналізувати, спрогнозувати ситуацію в межах природоохоронної місиевості та вжити заходів для збереження ландшафтів.

Ключові слова: дані космічних знімків, рослинні угруповання, ландщафт, індикативні ландшафтні об'єкти, національний природний парк.

А. Ю. ОвчаренКО. ВЫЯВЛЕНИЕ ИНДИКАТИВНОГО ЛАНДШАФТНЫХ ОБЪЕКТОВ В ПРЕДЕЛАХ ПРИРОДООХРАННЫХ ТЕРРИТОРИЙ. Работа посвящена идентификации ландшафтных объектов (растительные сообщества и водные объекты), которые изменяются в течение времени и влияют на структуру ландшафтных комплексов. Территория исследования находится в пределах природоохранной зоны, поэтому важным аспектом выявления индикаторов изменения ландшафтов уровня фаций является дистанционные методы исследования. Создание образа ландшафтной мозаики с помощью космических снимков Sentinel-2, Planet Scope, Landsat-8 позволяет составить карту-гипотезу, сформировать базу данных и проанализировать образ, созданный дистаниионно. Автором была сформирована методика составления ландшафтной карты, выявления индикативных объектов и проведены экспериментальные работы с помощью выбора конкретных данных космических снимков и инструментария обработки. Обработка данных космических снимков дает возможность анализировать труднодоступные территории, например те, что находятся в зоне повышенной охраны или районы в городах болот, густых лесов, гор и т. д. В процессе составления методических аспектов были использованы и апробированы несколько методов классификации космических снимков: использовали автоматическую и ручную обработку. В частности, лучшие результаты получены методом контролируемой классификаиии. Выбор космических снимков и его пространственного расширения зависит от задач, поставленных перед исследователем, площади территории, характера разнообразия объектов и наличие возможностей покупки или открытого использования данных. Выбор индикаторов значительно зависит от технической обработки данных, визуального и программного анализа отдельной территории. Для природоохранных территории важно учитывать специфику местности и характер изменчивости образа ландщафтов под влиянием природных и антропогенных факторов (так как на природоохранные территории влияет хозяйственная деятельность человека и они созданы как природные резерваты экосистем и их отдельных компонентов). Выявление индикаторов позволяет проанализировать, спрогнозировать ситуацию в пределах природоохранной территории и принять меры для сохранения ландшартов.

Ключевые слова: данные космических снимков, растительные сообщества, ландшафт, индикативные ландшафтные объекты, начиональный природный парк.

Formulation of the problem. The article presents the results of a study of indicative landscape objects of nature protection territories using the example of Slobozhanskiy National Nature Park in the Kharkiv region, the Ukraine. The authors propose the creation of an image of an object and its visualization using the means of geographic information systems. The choice of various types of satellite images to obtain relevant information at the time of the study, depending on the specific tasks, is justified. The selection of indicative objects and their characteristics is analyzed. It was experimentally deter- mined that indicative objects, information about which can be regularly obtained from satellite images, include plant communities and the contours of water bodies that form landscapes (facies level).

The best way to obtain reliable information from satellite images was determined by the methods of controlled classification (creating a layer of reference sections), namely "Minimum Distance". For reliability and a more accurate definition of the contours, it is necessary to first divide the studied territory into parts with relatively uniform terrain characteristics. Experimentally, the authors selected 
the optimal number of classes for each study area, taking into account the task (generalization or a more detailed description of the surface).

Literature Review. M. D. Grodzynsky created a new vision of the landscape as a separate natural unit (2018) [8]. Researchers from Estonia (Villoslada M., Bunce R., Sepp K., Burdun J. et al.) had modelled construction and validation of the Environmental Stratification of Estonia using framework for habitat monitoring and climate change (2017) [19]. Monitoring ecological consequences of efforts to restore landscape-scale connectivity was held by Watson D., Doeer V., Banks S. et al (2017) [2, 20]. $\mathrm{H}$. Alfan was analyzing landscape changes as an indicator for environmental monitoring (2017) [1]. Monitoring and modelling landscape dynamics were showed in works of Houet T., Verburg P., Loveland T. (2010) [11]. Development of the method for monitoring the condition of forests based on the use of multispectral space survey data had researched by Bogdanov A. P., Aleshko P. A. (2016) [9, 5, 13, 14]. Determination of forestness and quantitative characteristics of forests on space images of Sentinel-2 (on the example of Shebekinsky municipal district of Belgorod region) was learned by Perepechena Yu. I., Glushenkov O. I., Korsikov R. S. (2017) [16]. Verification using long-term data in an arid grassland ecosystem, Indicators and reference values for Swiss llandscapes were obtained by the researchers while using remote sensing data (Sentinel-2, PlanetScope, MODIS, MOCUPP) [3]. Some reports informed of biodiversity monitoring while using the description of all nature and social landscape components. For example, Terrestrial Monitoring Program. Each of these works consists of some information about indicative object as specific tasks of specific objects were showed in landscape $[6,10]$.

Selection of previously unsolved parts of the overall problem. Protected areas need timely identification of changes and their assessment. Using open satellite imagery data allows obtaining information on the state of natural objects of the study area relatively quickly. In addition, the processing of this kind of data helps to form the basis for analysis and forecasting changes to improve the state of objects of interest. The possibility of processing Earth remote sensing data helps to obtain information about the status of identical objects in hard-to-reach places and where access to human activity is prohibited (swamp areas, inland desert areas, mountainous areas, etc. reserves and national parks). Depending on the spectral features of space images and resolution, it can investigatively analyze objects of different shapes, sizes, and surface roughness [17]. Experimental studies have shown the possibility of obtaining characteristics of indicator objects of environmental change using different types of satellite images and processing methods in different information programs.

Formulation of the purpose of the article. The main goal is to select landscape objects to identify and predict changes, definitions of methods and tools for monitoring studies.

\section{Materials \& Methods.}

Study area. This study focused on an area of the National Nature Park (NNP) “Slobozhanskiy” (Fig. 1),

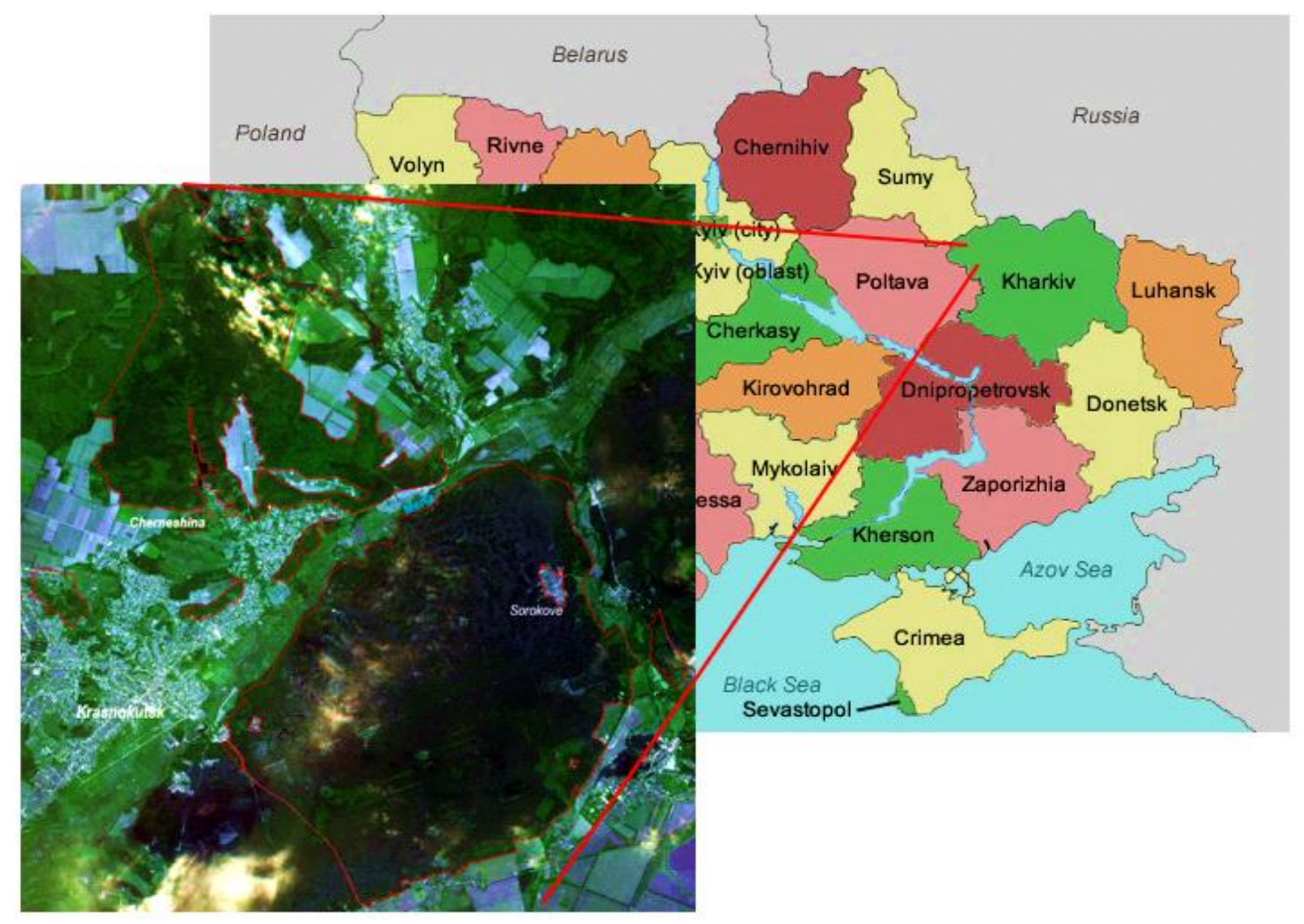

Fig. 1. Location of the study area (Sentinel-2) 
Krasnokutsk district, Kharkiv region in Ukraine.

This park is situated within forest-steppe zone, but it has some objects as objects of mixed forest zone. NNP "Slobozhanskiy" is a new park. It was created in 2009. The national nature park is researched little. The greatest value of the park is the presence of ancient lakes and swamps. The area is situated within the valley of Merla river. It has some parts that have different geophysical characteristics $[4,7]$.

Most of the territory is located on the surface of the first over-flooded terrace. Relief is mixing of raising and lowering land.

\section{Description of the Data}

Using differently remote sensing data gives different contours. That is why the authors experimentally select types of data for tasks. It depends on square of research area and details of tasks [15].

Landsat 8 has 9 multispectral bands with resolution $30 \mathrm{~m}$ and $15 \mathrm{~m}$ - Panchromatic.

Sentinel 2 as Landsat 8 are open data. That is why they are used by researchers. Remote sensing data of this type consists band set with resolution $10 \mathrm{~m}, 20 \mathrm{~m}, 30 \mathrm{~m}, 60 \mathrm{~m}$.

\section{Selection of indicative objects}

For different type of remote sensing data characteristically some indicative object for draws (automatically) contours. But we took changing plant communities as indicator changing of landscape. And changing contour of waterbodies are indicators of changing plant communities [14].

Selection of methods and instruments of programs

Based on spectral characteristics bands of different remote sensing data can be used methods of creating index NDVI (The Normalized Difference Vegetation Index and NDWI (The Normalized Difference Water Index) for selection plant communities and waterbodies. But we used information about some characteristics from reconnaissance of territory, information from park chronicle (Fig. 2).

Maps, statistics information from chronicle of reserved objects, reconnaissance gives primary data for creating landscape on some moment time. GISsystems (Geoinformational geography system) like ArcGis and QGis with moduls of SAGA are used for vectorization data, creating database of "landscape imagery".

For data of landscape's components we vectorized from topography map (relief), soil map (soil),

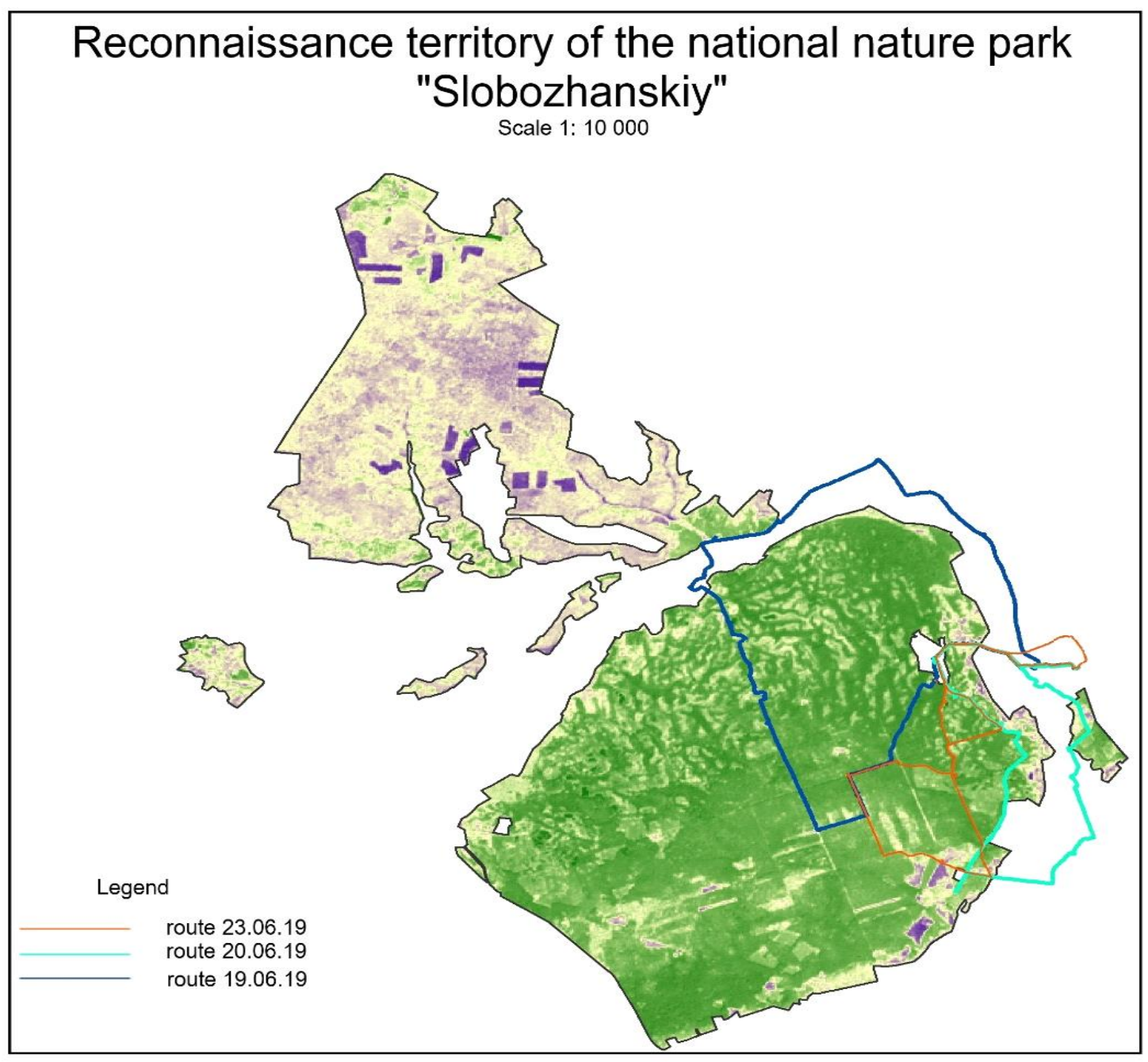

Fig. 2. Thematic imagery of reconnaissance (created with students) 
geomorphology (geology) (Fig. 3).

Classification as method of identify indicative objects

In the process of our research we were identifying «differently surface». There are counters of plant communities, open areas with sand, waterbodies. We used different methods of classification. Image classification refers to the task of extracting information classes from a multiband raster image.

The resulting raster from image classification

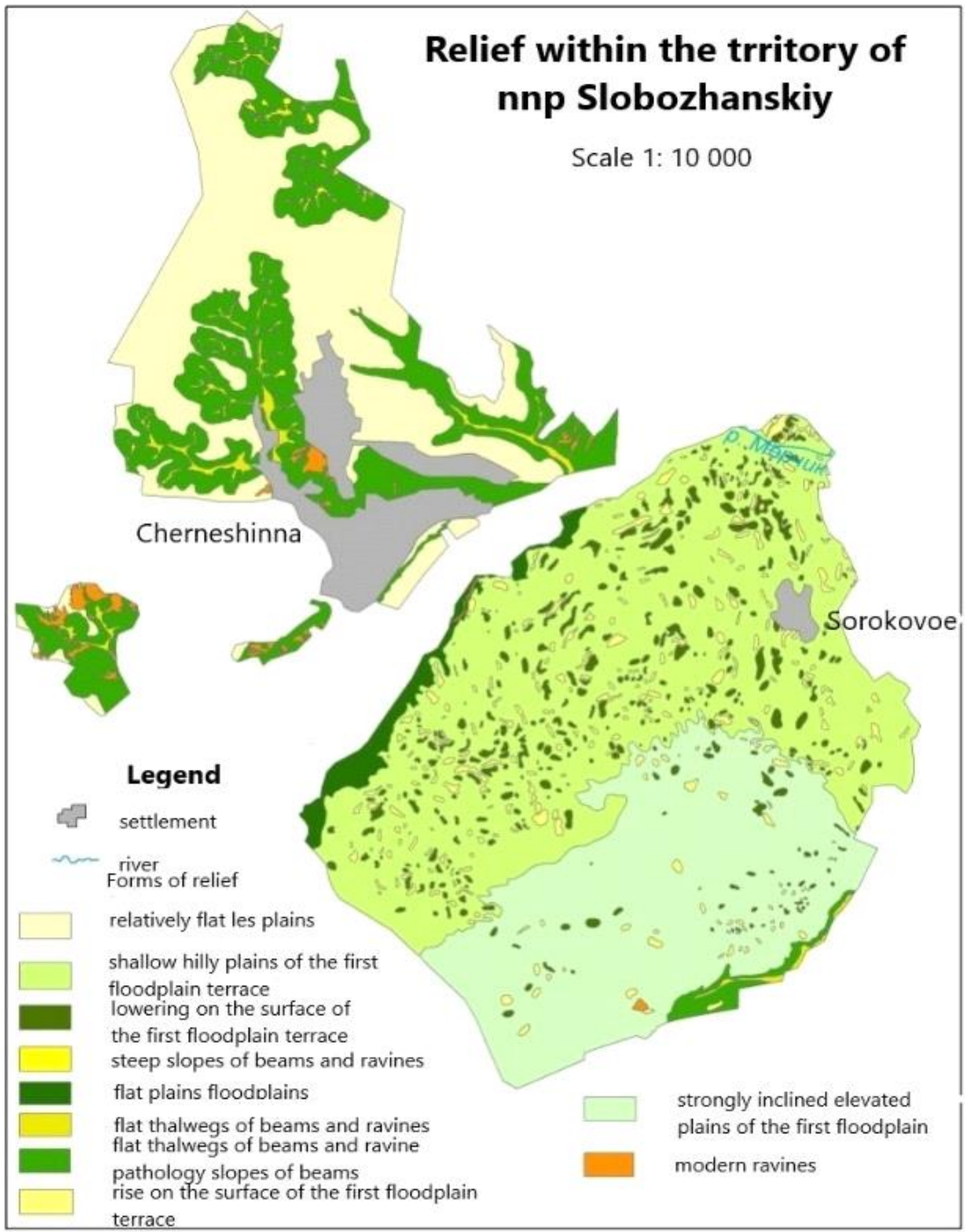




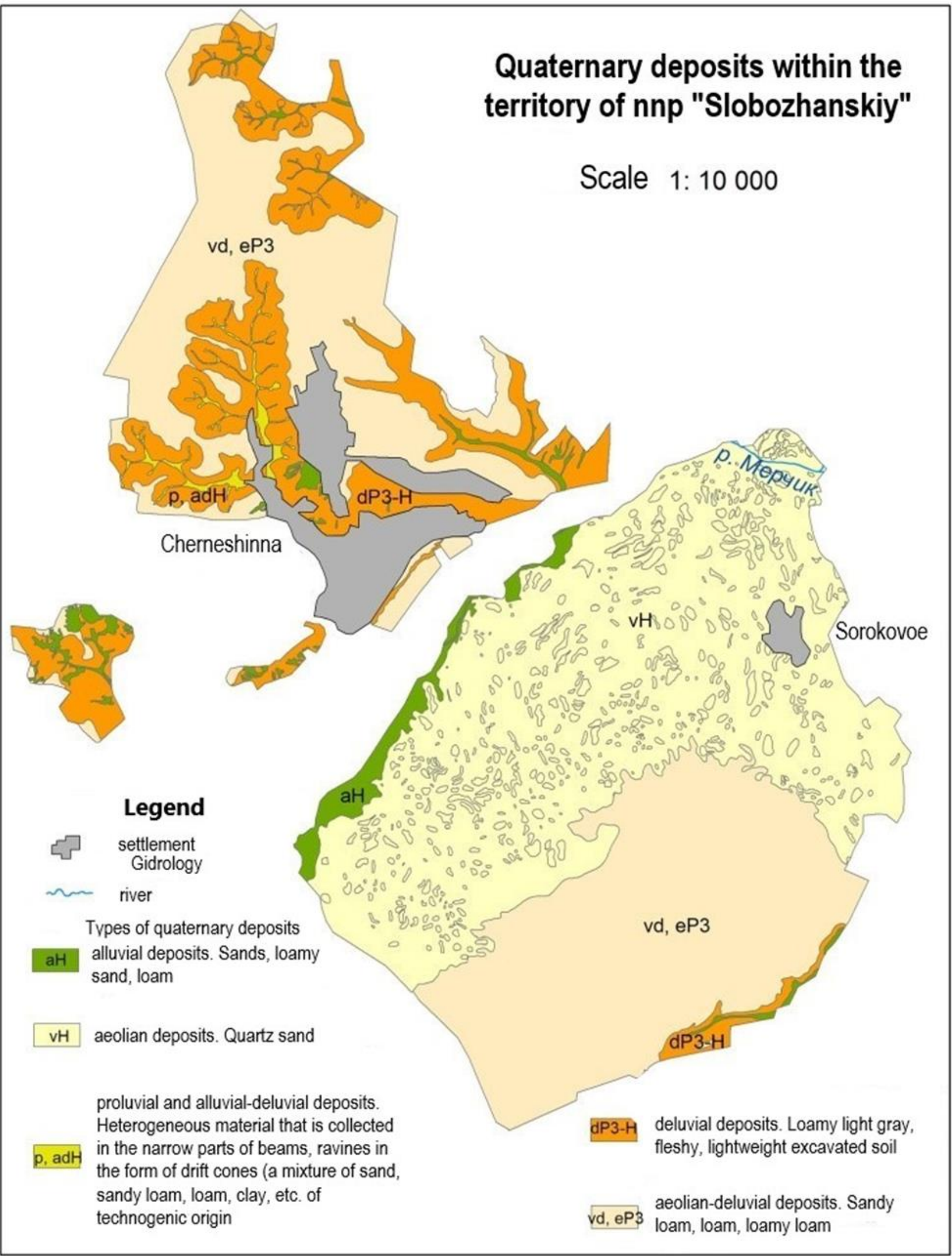




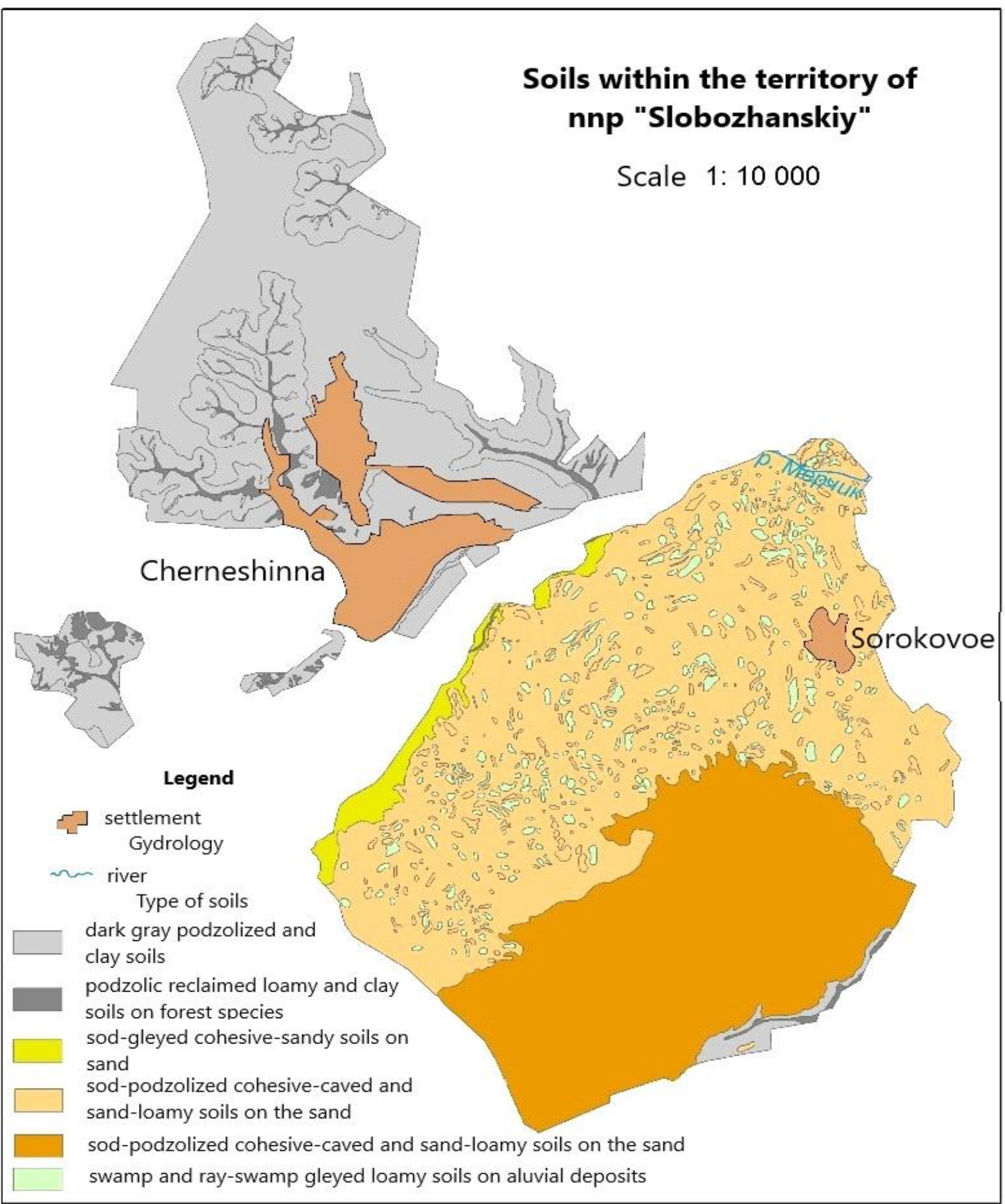

c

Fig. 3. Thematic maps: $\mathrm{a}-$ forms of relief, $\mathrm{b}-$ geomorphology, $\mathrm{c}-$ soil

can be used to create thematic maps.

Based on experiments we chosen supervised classification (Fig. 4). Because researcher identifies contours according to their ideas and specific knowledge after reconnaissance of the territory. Nil Armstrong said that machines are getting better, but, fortunately, there is still room for us, homo sapiens, and some reason to continue to exist. These words can be about semi-automatically classification. We selected methods experimentally. An important feature of the classification is the representation of the landscape after reconnaissance and the ability to classify objects visually for more accurate machining.

\section{Working with SAGA}

Saga was used for Landsat 8 data. Thematic imagery had resolution $-30 \mathrm{~m}$, after process with panchromatic band was $15 \mathrm{~m} \mathrm{[18].}$ 
We can use spectral interval for identification, but whole picture of landscape we don't have (table 1). "Landscape`s name" consists geology and geo- morphology, soils, plant communities. But our researching of Landsat 8 was directed to the allocation of vegetation contours (Fig. 5).

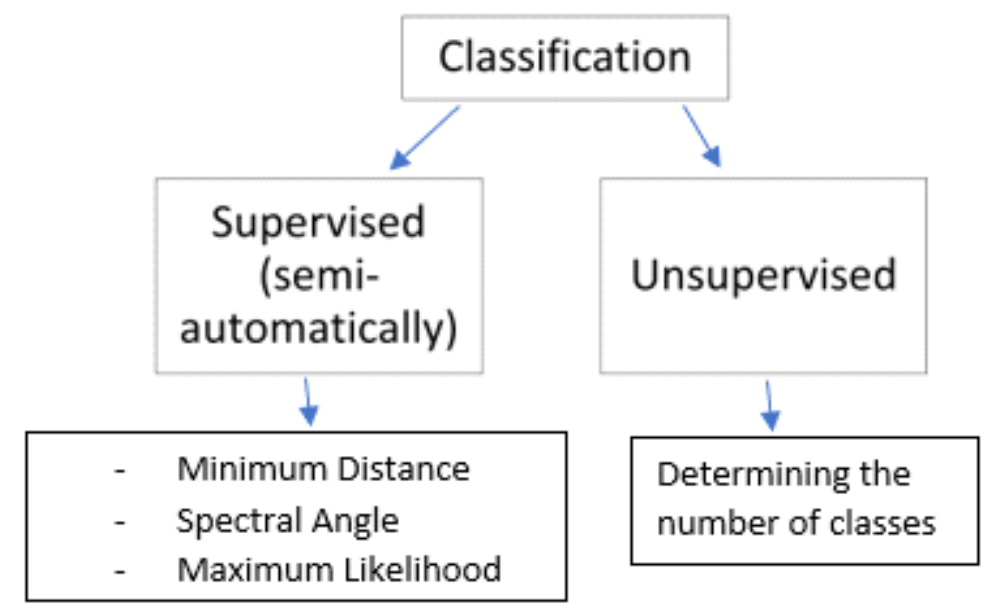

Fig. 4. Standard types of classification

Table 1

\begin{tabular}{|c|c|l|l|}
\hline $\begin{array}{c}\text { № } \\
\text { diapasons }\end{array}$ & Spectral intervals (mkm) & \multicolumn{1}{|c|}{ Objects, that are indicated } & \multicolumn{1}{|c|}{ Objects, that aren`t indicated } \\
\hline 1 & $0,45-0,515$ & Ever greens & Swamps and waterbodies \\
\hline 2 & $0,525-0,605$ & Active vegetation plants & Cutting forest and water surface \\
\hline 3 & $0,63-0,69$ & Different types of plants, felling & Water surface \\
\hline 4 & $0,75-0,9$ & Open waterbodies or swamps & Hardwood \\
\hline
\end{tabular}

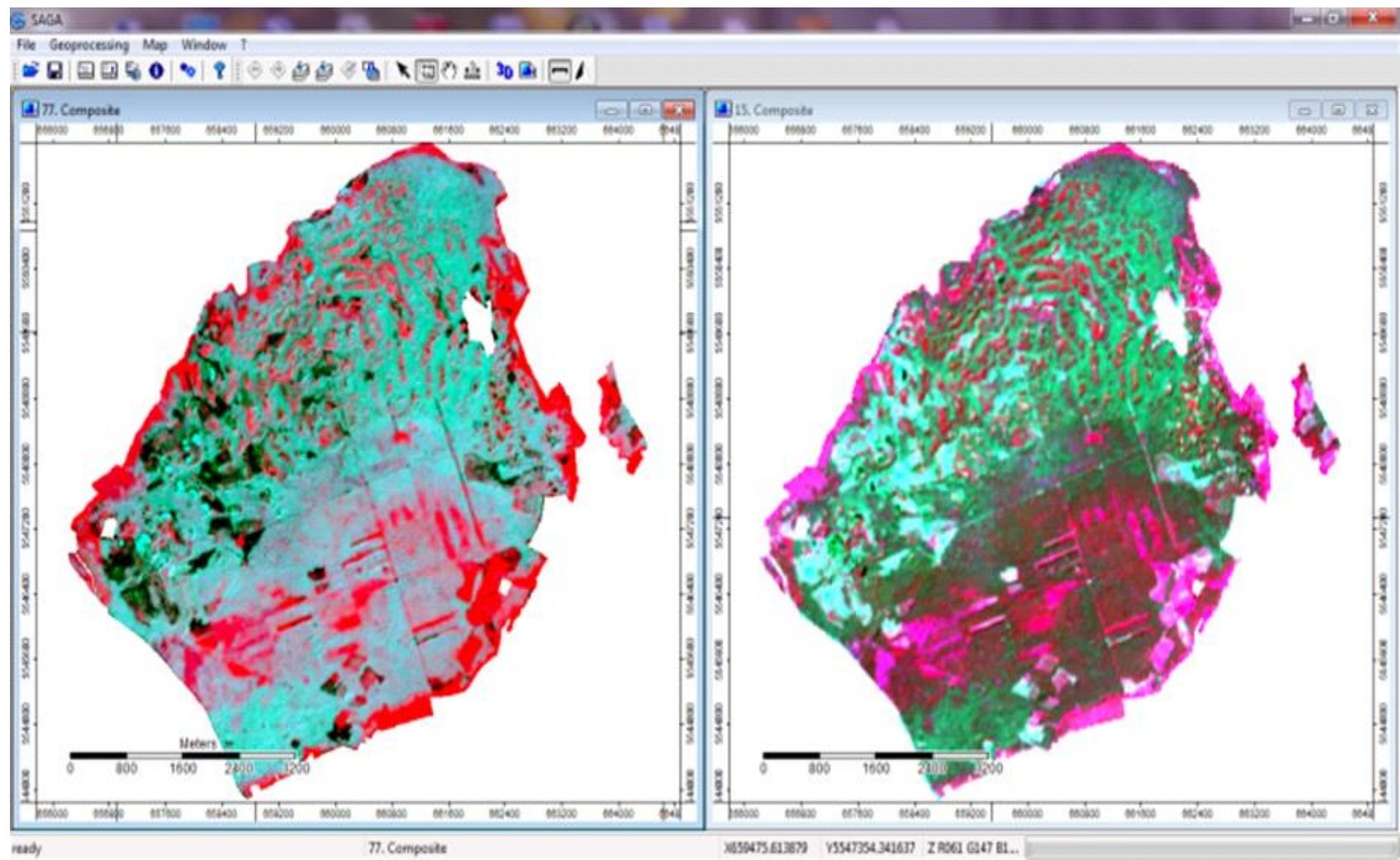

Fig. 5. Composition imagery of Landsat 8 (combination band set 5,4,3 - nature colours) with resolution $15 \mathrm{~m}$ (after panhrome processing)

Every identify areas was selected by researches according to landscape considerations. There are different methods of classification. We compared "Parallelepiped" and "Spectral Angle Mapping". 


\section{Working with program QGis}

OGis is open program and has plugin semiautomatic classification for working with open remote sensing data (resolution 10, 20, 30, $60 \mathrm{~m}$ ) Sentinel-2. Algorithm of creating thematic imagery using Sentinel-2 data presented in the figure 6.

Working with program ArcGis
For classification imagery we need to create vision.

In ArcGis we used two types of remote sensing data. There are Sentinel-2 and Planet Scope that have high resolution $-3 \mathrm{~m}$ (Planet Scope) and $10 \mathrm{~m}$ (Sentinel-2) (Fig. 7).

For working with Planet Scope we used unsu-

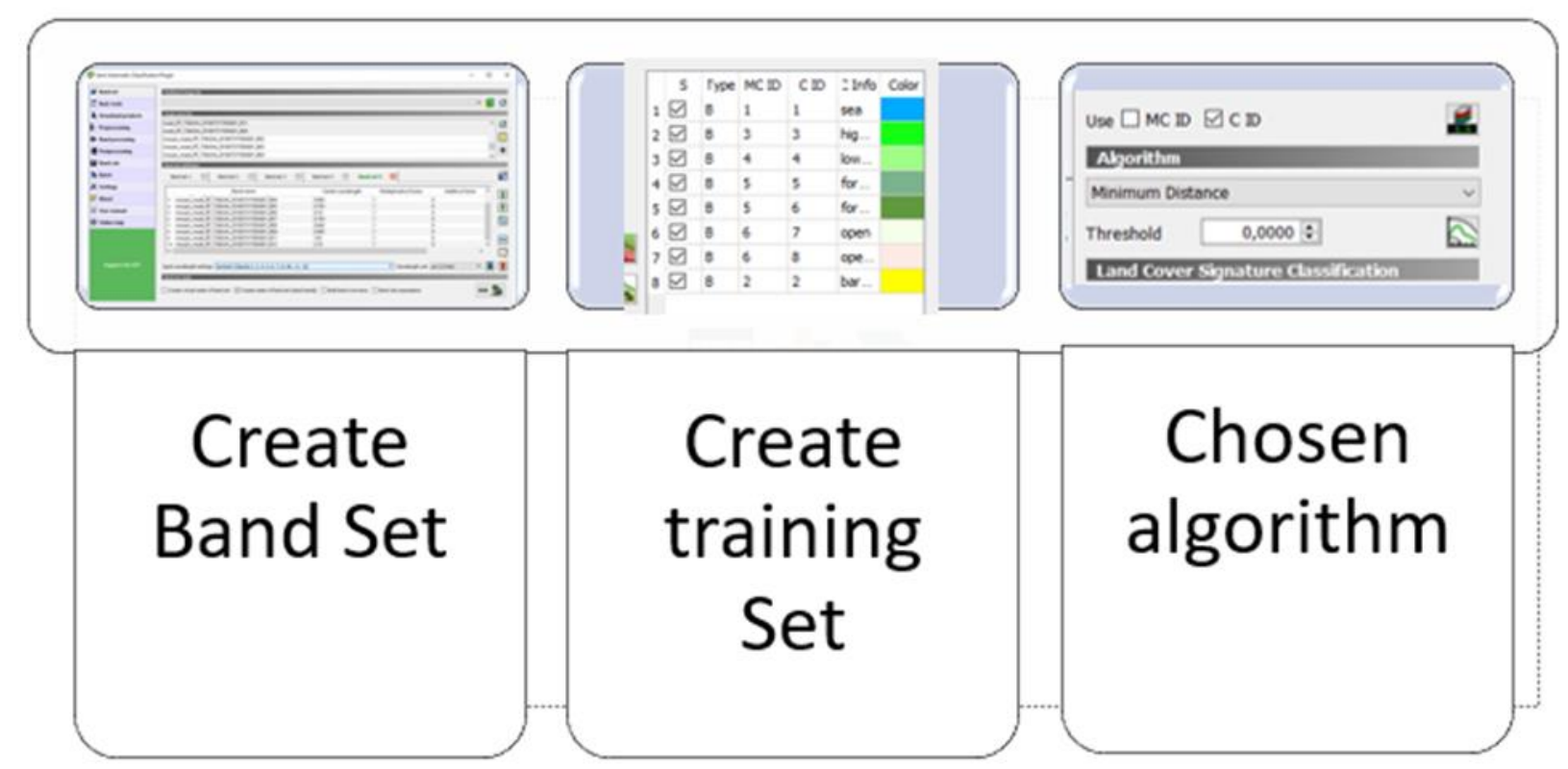

Fig. 6. Creating thematic imagery in QGis

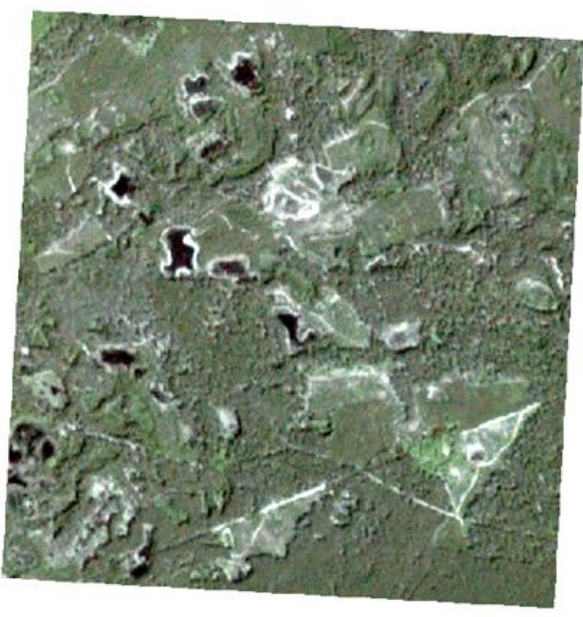

a

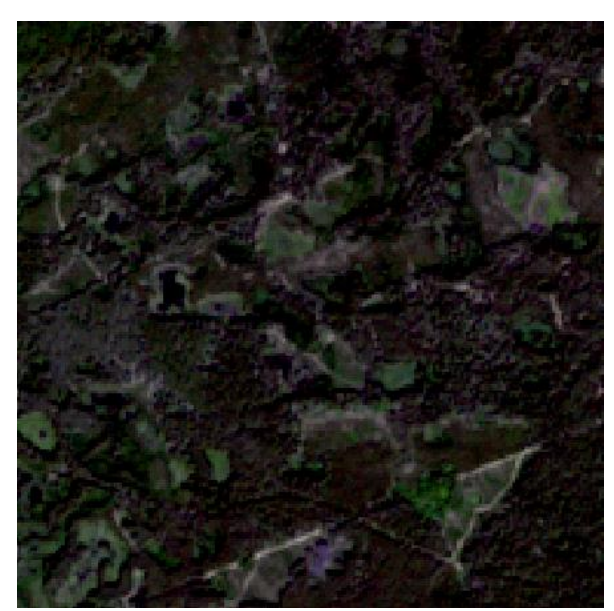

b

Fig. 7. Image composite: $a-$ Planet Scope, $b-$ Sentinel-2

pervised and supervised methods of classification.

Working with Sentinel-2 data in ArcGis need preprocessing in QGis (creating band-set).

For comparison, based on experiments, different remote sensing data gives more or less detail information about surface of interest. When we need more detail information's we can use Planet Scope and as result we get mosaic structure of plant communities and other objects contours. That is why we create thematic image for small area.

\section{Results}

For recognition of indicative landscape objects within protected areas we experimentally selected processing methods and data (Fig. 8). Our results gave information on the possibilities of identifying the characteristics of index objects for different tasks.

We used different programs to get a more accurate image. Landsat 8 data have resolution $15,30 \mathrm{~m}$. That is why we got a generalized image.

Experimental researches show that Merla river shares two parts of park. In the north part is oak grove, in south is pine forest (Fig. 9). 
We got the best results using Sentinel-2 data and Planet Scope data.

Authors used methods in programs: QGis Minimum Distance, Maximum Likelihood, Spectral Angle Mapper of supervised classification for Sentinel-2, ArcGis - unsupervised classification and Maximum Likelihood for Planet Scope.
Comparing methods the best results obtained using method "Minimum distance" of Sentinel-2 in QGis (Fig. 10).

The purpose of all attempts at classification was to find the optimal number of classes for the interpretation of plant communities (Fig. 11).

Many classes made the thematic image unread-

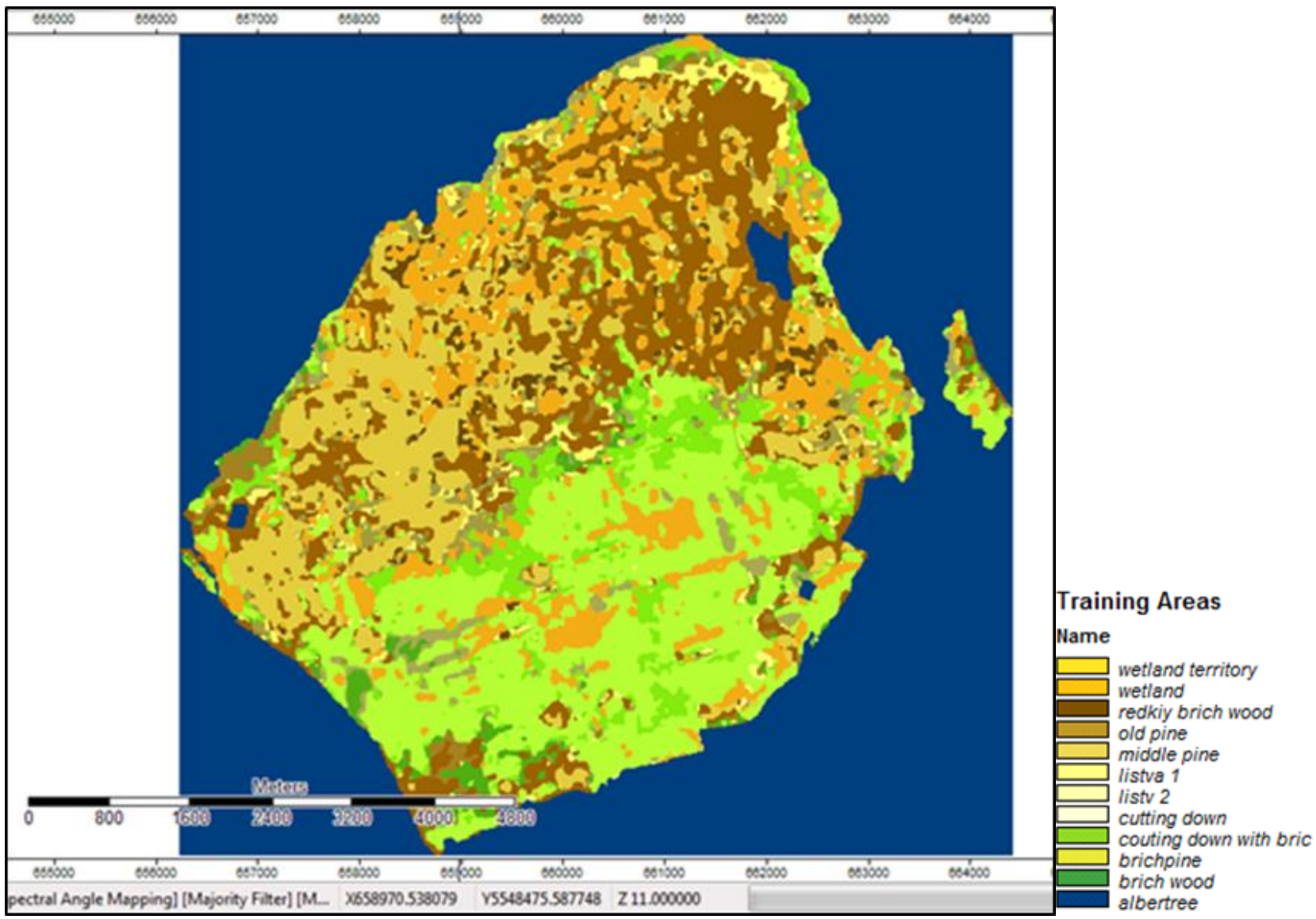

Fig. 8. Thematic imagery Landsat 8 in SAGA

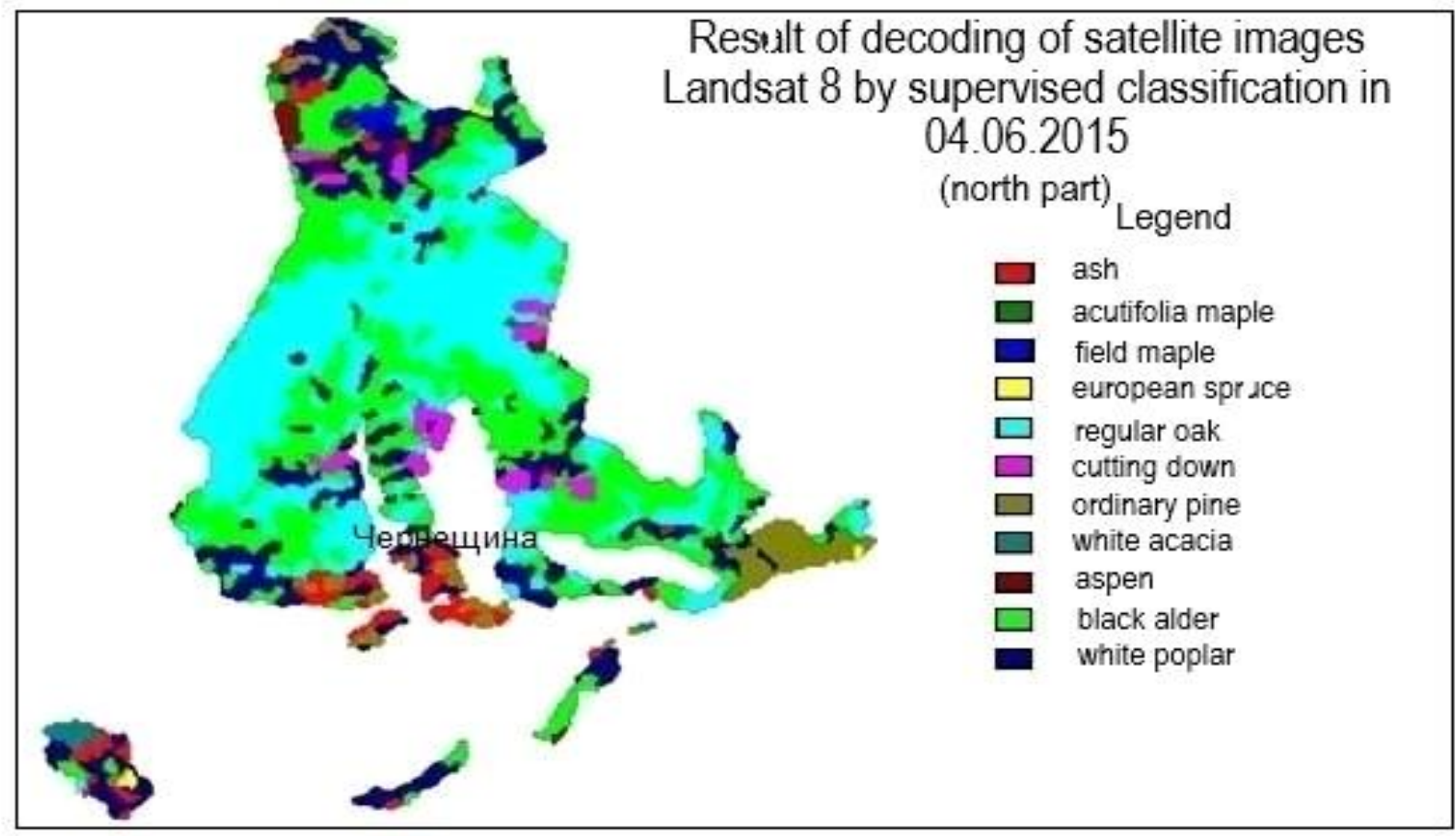




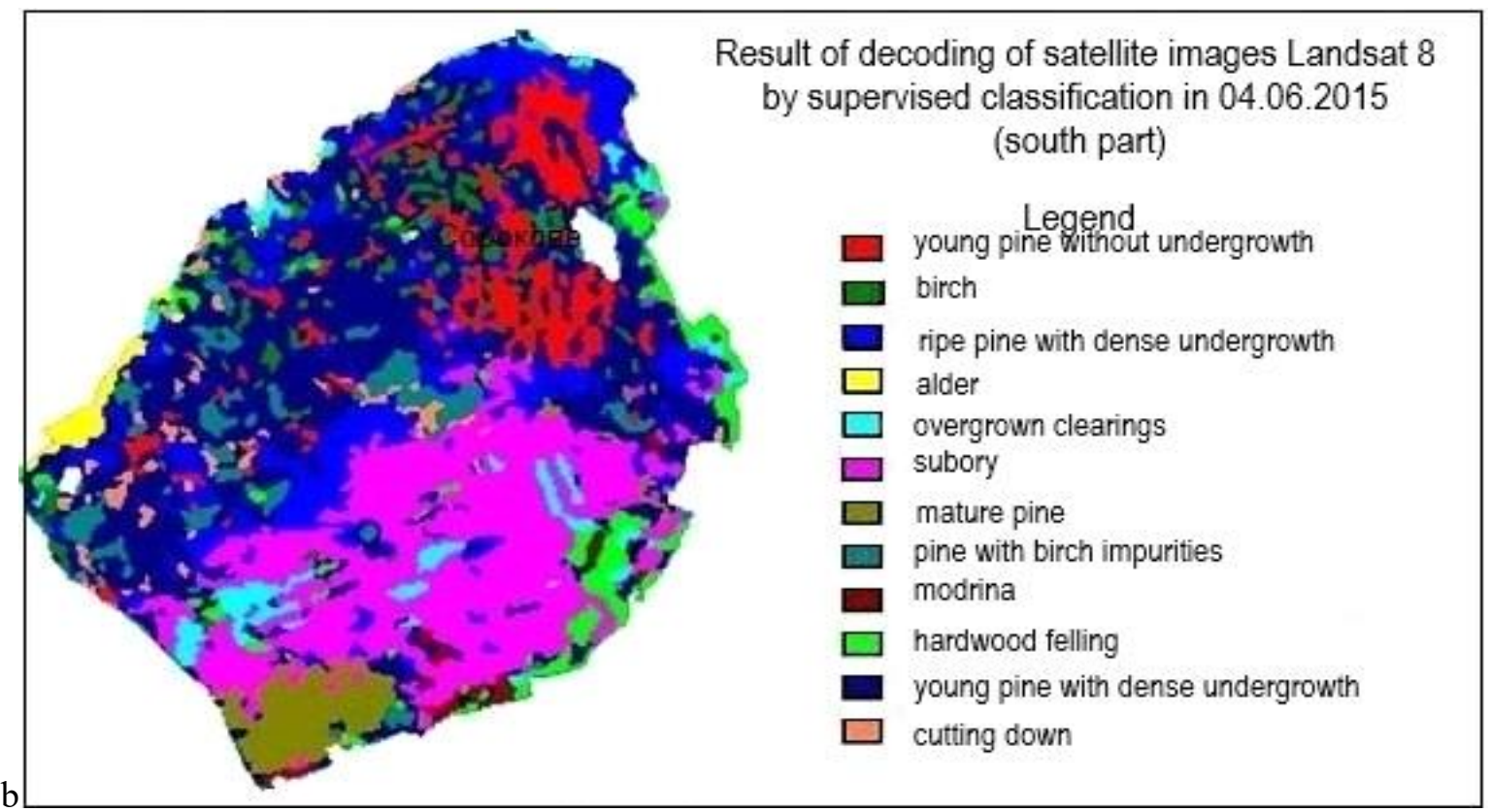

Fig. 9. Results of decoding of satellite images Landsat 8 in SAGA: $a$ - north part, $b$ - south part
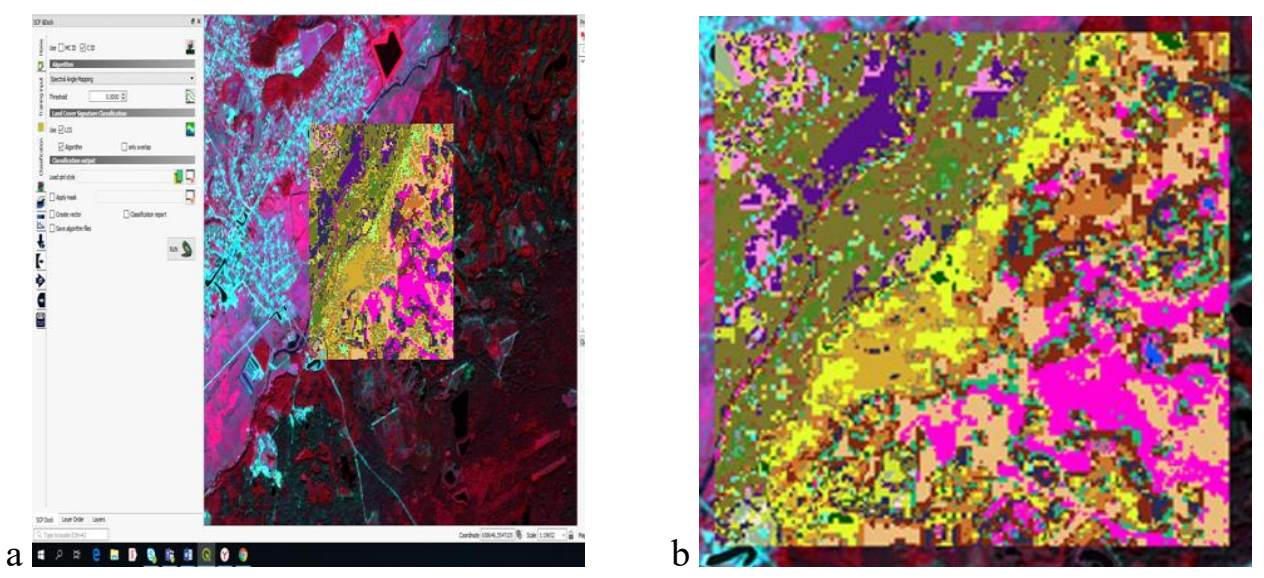

Fig. 10. Using methods of supervised classification: $a$ - minimum distance, $b$ - spectral angle mapper
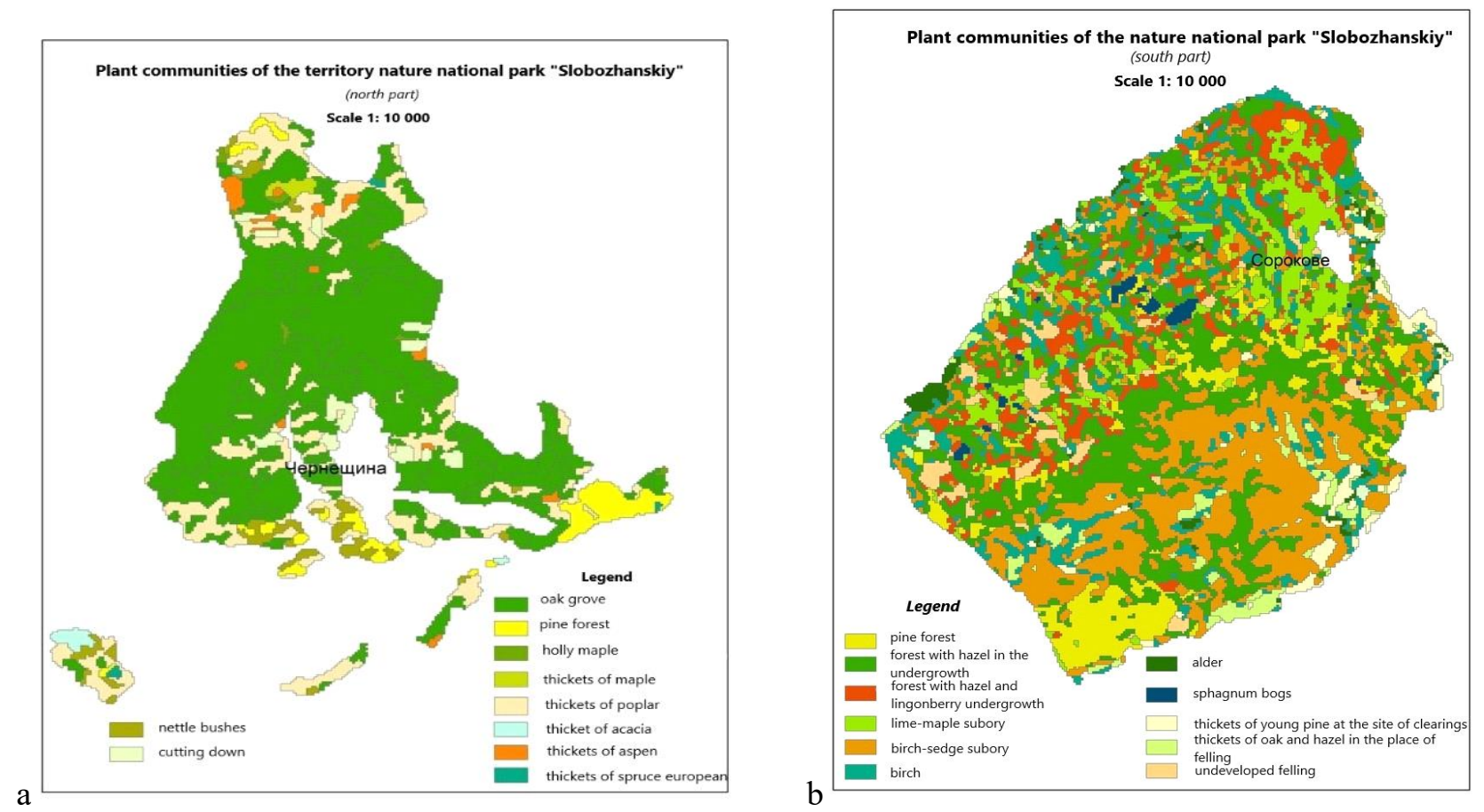

Fig. 11. Thematic imagery of plant communities in north part of NNP "Slobozhanskiy" (a) and south part (b) 
able. The small number of classes does not allow more or less full coverage of the diversity of plant communities. Therefore, the best results were obtained with the allocation of 11 classes for the southern part of the park and 8 classes - for the north.

In ArcGis we processed Planet Scope. For example, was researched area on the east of south part of the national nature park "Slobozhanskiy" (Fig. 7).

\section{Post-classification process}

Post-classification processing consists of several stages. Our objects are landscape. That is why we need methods of generalization for creating contours
(Fig. 12). The best results got by "Nearest Neighbor" methods.

Using methods: "Intersect" (intersect contours of plant communities, forms of relief, geology and soil structure - it is contour of landscape), "Dissolve" (combining repeating contour names into one type) allowed to create unique landscape contours for visual showing in map and database (Fig. 13). This information was can used for landscape and other type of monitoring within protected areas.

\section{Conclusion and perspectives}

Selection of indicative landscape objects depends on the tasks assigned to the researchers. In
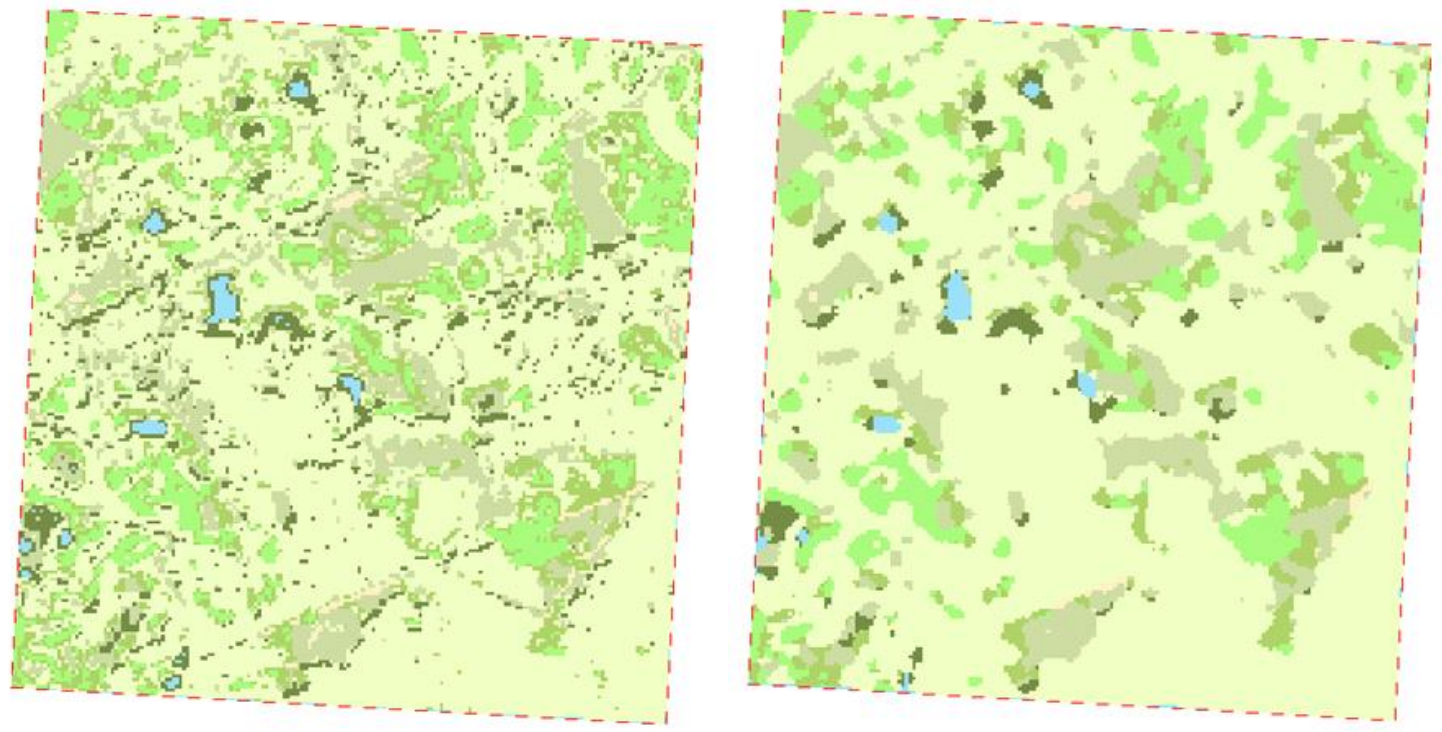

Fig. 12. Using two methods of generalization: Nearest Neighbor (a) and Majority (b)

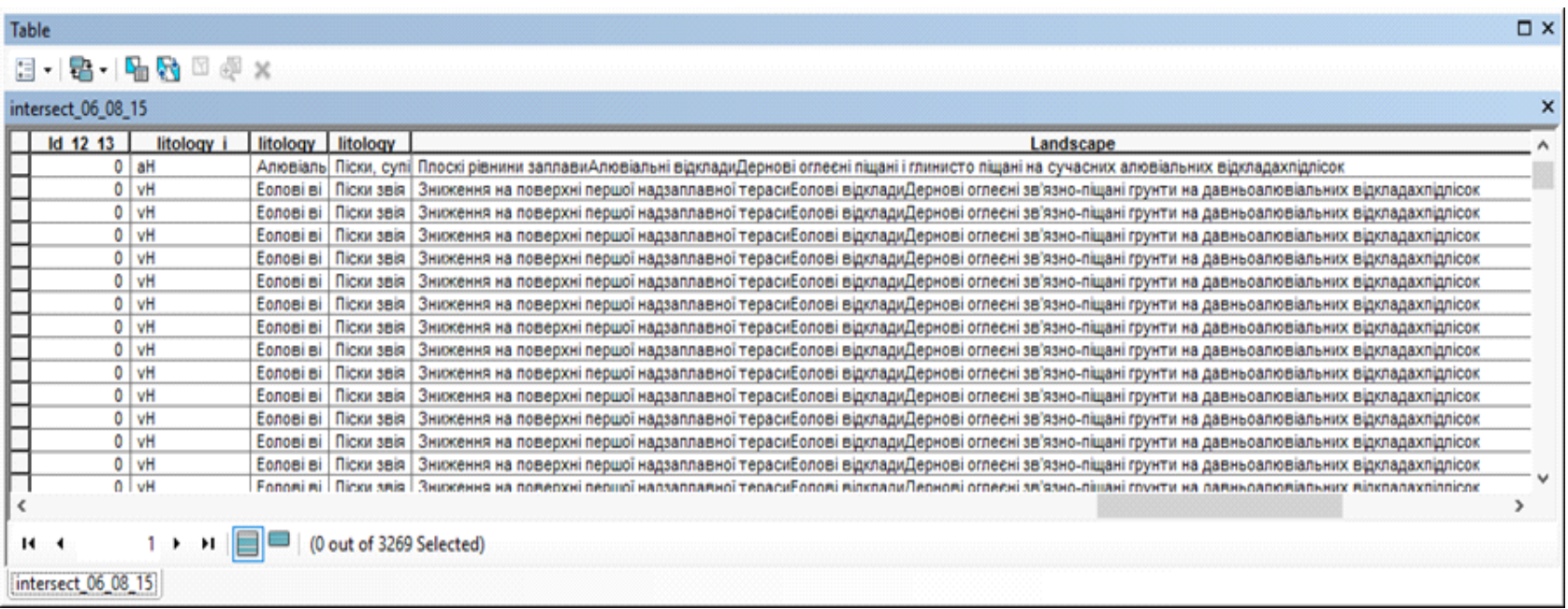

Fig. 13. Database of landscape structure

most cases, their definition depends on changes that change the characteristics of the entire landscape system and need regular monitoring, analysis and forecasting of the situation. To isolate objects, we formed a picture of images from those objects that we can double out from satellite imagery data ac- cording to the level of resolution and described the results of "imagination".

The use of Sentinel-2 and Planet Scope space images (13 optical channels, scanning intervals of 23 days, up to $3 \mathrm{~m}$ resolution on terrain), which are best suited for high-precision monitoring, and Planet 
Scope for small study areas have been experimentally determined.

The necessity and possibility of using modern

space information not only to clarify the contours and fill the landscape features, but also to trace the changes of wetlands that should be indicators of monitoring are investigated.

\section{Bibliography}

1. Alfan H. Spatial pattern of illegal activities and the impact on wildlife populations in protected areas in the Serengeti ecosystem / H. Alfan // PhD thesis. - York : University of York, 2017. http://etheses.whiterose.ac.uk/ id/eprint/20276

2. Bastian O. A framework for monitoring landscape functions: The Saxon Academy Landscape Monitoring Approach (SALMA), exemplified by soil investigations in the Kleine Spree floodplain (Saxony, Germany) / O. Bastian, R. Roder, F. James. - Dresden : Landscape and Urban planning, 2007. - Vol. 79. - Issue 2. - P. 190-199. - DOI: https://doi.org/10.1016/j.landurbplan.2006.02.005

3. Бодня О. В. Індикативний ландмафтний моніторинг наиіональнихї природних парків (на прикладі території НПП «Слобожанський») / О. В. Бодня, А. Ю. Овчаренко // Вісник Харківського начіонального університету ім. В. Н. Каразіна. - Харків, 2018. - Bun. 49. - C. 192-207. - DOI: https://doi.org/10.26565/2410-7360-2018-49-15

4. Бятов А. П. Додаток до Літопису природи наиіонального природного парку «Слобожанський» за 2012 рік / А. П. Бятов, Н. О. Бруснеиова, Н. В. Сядаксмедова [та ін.]. - Краснокутськ, 2013. - 136 с. https://zakon.rada.gov.ua/rada/show/v465 737-02/card6\#Public

5. Богданов А. П. Разработка методки мониторинга состояния лесов на основе использования данных мультиспектральной космосьемки / А. П. Богданов, Р. А. Алешко. - Архангельск : ФБУ «Северный научноисследовательский институт лесного хозяйства», 2016. - C. 98-110. - DOI: https://doi.org/10.21513/02072564-2017-1-98-110

6. Cheng Y. Retrieving vegetation phenology with planetscope images for a semi-arid rangeland in Kenya / Y. Cheng. Enschede, 2019. - 74 p. http://purl.utwente.nl/essays/83720

7. Горванова В. О. Особливості фізико-географічного районування в начіональному природному парку «Слобожанський». Умань, Екологія - шляхи гармонізаиі відносин природи та суспільства / В. О. Горванова, Р. О. Квартенко // Збірник тез III Міжнаодної конферениії (11-12 жовтня 2012 р.). - Умань, 2012. - C. 96-98.

8. Гродзинський М. Д. Географія: стара назва нової науки чи відродження вже майже забутого / М. Д. Гродзинський // Украйнський географічний журнал. - K., 2017. - № 2. - C. 65-68. - DOI: https://doi.org/10.15407/ugz2017.02.059

9. Hakan A. Analysis of landscape changes as an indicator for environmental monitoring / A. Hakan // Environmental Monitoring \& Assessment. - 2017. - Vol. 189. - P. 1-10.

10. Hakkenberg C., Song C., Peet R. Remotely-sensed predictive models of forest composition: community-unit classification versus continuous gradient modeling / C. Hakkenberg, C. Ssong, R. Peet. - 2016. - 2016AGUFM.B52A...07H

11. Houet T., Verburg P., Loveland T. (2010). Monitoring and modelling landscape dynamics / T. Houet, P. Verburg, T. Loveland // Landscape Ecology. - Vol. 25. - P. 163-167.

12. Lambin E. (2001). Remote Sensing and Geographic Information Systems Analysis / E. Lambin // International Encyclopedia of the Social \& Behavioral Sciences. - Louvain-la-Neuve. - P. 13150-13155.

13. Landscape monitoring using remote sensing NAU students in the Department of Geography, Planning, \& Recreation study the desert. https://nau.edu/gpr/landscape-monitoring-using-remote-sensing

14. Овчаренко А. Ю. Можливості ГІС-технологій в аспекті здійснення крупномасштабного ландмафтного картографування і польових практиках студентів-географів / А. Ю. Овчаренко // Збірник науковизх праць «Проблеми безперервної географічної освіти і картографіїі» (на сайті Наиіональної бібліотеки України імені В. I. Вернадського). - Харків, 2019. - Bun. 30. - C. 70-80. - DOI: https://doi.org/10.26565/2075-1893-201930-08

15. Овчаренко А. Ю. Огляд досліджень індикативних об'єктів ландмафтного моніторингу з використанням даних ландшафтного моніторингу з використанням даних Д3З / А. Ю. Овчаренко // Географічні дослідження: історія сьогодення, перспективи: матеріали щорічної міжнародної наукової конференції студентів $i$ присвяченій пам'яті професора Г. П. Дубинського (11 квітня 2019 року). - Харків, 2019. - Вип. 12. - С. 39-44.

16. Перепечина Ю. И. Определение лесистости и количественных характеристик лесов по космическим снимкам Sentinel-2 (на примере па primere Шебекинского муниципального района Белгородской обл.) / Ю. И. Перепечина, О. И. Глущенков, О. И. Корсиков // Дистаниионные методы в лесном хозяйстве. - 2017. - № 4. - С. 85-93. https://cyberleninka.rul

17. Somers B. Endmember Library Approaches to Resolve Spectral Mixing Problems in Remotely Sensed Data: Potential, Challenges, and Applications / B. Somers, L. Tits, D. Roberts [and others] // Data Handling in Science and Technology. - Leuven, 2016. - Vol. 30. - P. 551-577

18. Tretyakov O. S. Features of interpretation of plant association of national natural park «Slobozhanskiy» using Landsat 8 satellite data / O. S. Tretyakov, O. V. Bodnia, M. O. Balynska et al // Problemy bezperervnoyi geografichnoyi osvity i kartografiyi: Zbirnyk naukovyx pracz. - Kharkiv, 2019. - Vol. 21. - P. 73-79. 
19. Villoslada M. A framework for habitat monitoring and climate change modelling: construction and validation of the Environmental Stratification of Estonia / M. Villoslada, R. Bunce, K. Sepp et al // Regional Environmental Change. - 2017. - Vol. 2. - P. 335-349. - DOI: https://doi.org/10.1007/s10113-016-1002-7

20. Watson D. Monitoring ecological consequences of efforts to restore landscape-scale connectivity / D. Watson, $V$. Doeer, S. Banks et al // Biological Conservation. - 2017. - Vol. 206, 201-209. - DOI: https://doi.org/10.1016/j.biocon.2016.12.032

UDC 9.502.4:502.5/8

\author{
Alina Ovcharenko, \\ PhD Student (Geography), V. N. Karazin Kharkiv National University, \\ 4 Svobody Sq., Kharkiv, 61022, Ukraine, \\ e-mail: alina_06ov@ukr.net, https://orcid.org/0000-0002-8500-4152
}

\title{
RECOGNITION OF INDICATIVE LANDSCAPE OBJECTS WITHIN PROTECTED AREAS
}

Formulation of the problem. In this article the author describes monitoring of landscape objects within protected area. We created 'image of landscape' from remote sensing data. The developed methodology allows to obtain remotely information about visual changes, to analyze and predict the further development of landscapes of the facies level. It is difficult to investigate nature conservation areas at the facies level in areas with plant diversity. Field methods are time-consuming and labor-intensive, but changes can occur frequently. We offer a methodology for identifying indicative landscape objects by creating an image and its visualization using high-resolution satellite imagery decoding Sentinel-2 (resolution $10 \mathrm{~m}$ ) and Planet Scope (resolution $3 \mathrm{~m}$ ). This method with using satellite imagery of study makes it possible to gain access to the terrain that is accessible in hard-to-reach places, namely in swampy areas, in dense forest impassable territories and others.

The purpose of the article. The main goal is creating methodic for recognition indicative objects of landscape within protected territories through the appearance of visual changes by the cameral method.

Materials and methods. We have improved the method of processing satellite images to identify indicative objects of changes in landscapes at the facies level. We used the method of controlled classification to obtain "a picture" of the landscape in office conditions, carried out an analysis of comparison on the ground and identified objects of interest. Based on experiments we chosen supervised classification and methods for different resolution of remote sensing data.

Results and scientific novelty. We have changed the traditional landscape study process and approach in our work. We created a landscape rendering model and then carried out work directly on the ground, comparing the characteristics. this allows you to explore the territory at a distance, in hard-to-reach places and in protected areas, which allows a person to analyze information at a distance, predict and take further measures to preserve landscapes and individual objects.

Practical significance. Identification of indicative objects within protected areas allows monitoring changes in landscapes, analyzing and taking measures to preserve them. Systematization of the entire analysis during processing allows you to identify changes in time even in hard-to-reach regions and quickly receive information remotely. The analyzed data allow designing a successful combination of the normal functioning of nature and human activity.

Keywords: remote sensing data, plant communities, landscape, indicative landscape objects, national nature park.

\section{Reference}

1. Alfan H. (2017). Spatial pattern of illegal activities and the impact on wildlife populations in protected areas in the Serengeti ecosystem. York, PhD thesis, University of York. http://etheses.whiterose.ac.uk/id/eprint/20276

2. Bastian O., Roder M., James F. (2007). A framework for monitoring landscape functions: The Saxon Academy Landscape Monitoring Approach (SALMA), exemplified by soil investigations in the Kleine Spree floodplain (Saxony, Germany). Dresden, Landscape and Urban planning, 79, 2, 190-199. https://doi.org/10.1016/ j.landurbplan.2006.02.005

3. Bodnya O. V., Ovcharenko A. Yu. (2018). Indicative landscape monitoring of national natural parks (in the application of the territory of NPP "Slobozhanskiy"). Kharkiv, V. N. Karazin Kharkiv National University, 49, 192-207. https://doi.org/10.26565/2410-7360-2018-49-15 
4. Biatov A. P., Brusenczova N.O., Saidaxmedova N.B. et al. (2013). Appendix to the Annals of Nature of the Slobozhansky National Nature Park for 2012. Krasnokutsk, 136. https://zakon.rada.gov.ua/rada/show/v465_73702/card6\#Public

5. Bogdanov A. P., Aleshko R. A. (2016). Development of a method for monitoring the state of forests based on the use of multispectral space survey data. Arhangelsk, FBU «Severnyj nauchno-issledovatelskij institute lesnogo hozjajstva, 98-110. https://doi.org/10.21513/0207-2564-2017-1-98-110

6. Cheng Y. (2019). Retrieving vegetation phenology with planetscope images for a semi-arid rangeland in Kenya. Enschede, 74. http://purl.utwente.nl/essays/83720

7. Goryanova V.O., Kvartenko R.O. (2012). Special features of the physical and geographical area in the national natural park "Slobozhansky". Uman, Ecology - the way of harmonizing the common nature and suspension. (11-12 october 2012.), 96-98.

8. Grodzynskyj M.D. (2017). Geography: the old name of the new science and the revival of the forgotten. K, Ukrainian Geographical Journal, 2, 65-68. https://doi.org/10.15407/ugz2017.02.059

9. Hakan A. (2017). Analysis of landscape changes as an indicator for environmental monitoring. Environmental Monitoring \& Assessment. 189, 1-10.

10. Hakkenberg C., Song C., Peet R. (2016). Remotely-sensed predictive models of forest composition: community-unit classification versus continuous gradient modeling. 2016AGUFM.B52A..07H

11. Houet T., Verburg P., Loveland T. (2010). Monitoring and modelling landscape dynamics. Landscape Ecology, 25, 163-167.

12. Lambin E. (2001). Remote Sensing and Geographic Information Systems Analysis. Louvain-la-Neuve, International Encyclopedia of the Social \& Behavioral Sciences, 13150-13155.

13. Landscape monitoring using remote sensing NAU students in the Department of Geography, Planning, \& Recreation study the desert. https://nau.edu/gpr/landscape-monitoring-using-remote-sensing.

14. Ovcharenko A. Yu. (2019). Mobility of GIS-technologies in the aspect of the development of large-scale landscape mapping and practical practices of geography students. Kharkiv, "Problemy bezperervnoyi heohrafichnoyi osvity $i$ kartohrafiyi» (na sayti Natsional'noyi biblioteky Ukrayiny imeni V. I. Vernads'koho), 30, 70-80. https://doi.org/10.26565/2075-1893-2019-30-08

15. Ovcharenko A. Yu. (2019). Review of the study of indicative projects of landscape monitoring using a landscape monopolist using remote sensing technologies. Kharkiv, Geographical research: the history of today, prospects: materials of the international science conference of students and the commemoration of the memory of Professor G.P. Dubinsky (11 April 2019), 12, 39-44.

16. Perepechena Ju. I., Glushenkov O. I., Korsikov O. I. (2017). Determination of forest cover and quantitative characteristics of forests using Sentinel-2 space images (on the example of na primere of the Shebekinsky municipal district of the Belgorod region). Remote methods in forest, 4, 85-93. https://cyberleninka.ru/

17. Somers B., Tits L, Roberts D., Werherley E. (2016). Endmember Library Approaches to Resolve Spectral Mixing Problems in Remotely Sensed Data: Potential, Challenges, and Applications. Leuven, Data Handling in Science and Technology, 30, 551-577.

18. Tretyakov O.S., Bodnia O.V., M.O. Balynska et al. (2015). Features of interpretation of plant association of national natural park "Slobozhanskiy» using Landsat 8 satellite data. Kharkiv, Problemy bezperervnoyi geografichnoyi osvity i kartografiyi: Zbirnyk naukovyx pracz, 21, 73-79.

19. Villoslada M., Bunce R., Sepp K. et al (2017). A framework for habitat monitoring and climate change modelling: construction and validation of the Environmental Stratification of Estonia. Regional Environmental Change, 2, 335 349. https://doi.org/10.1007/s10113-016-1002-7

20. Watson D., Doeer V., Banks S. et al (2017). Monitoring ecological consequences of efforts to restore landscapescale connectivity. Biological Conservation. 206, 201-209. https://doi.org/10.1016/j.biocon.2016.12.032 